\title{
Identification of occupational mortality risks for Hanford workers
}

\author{
G W KNEALE, T F MANCUSO, AND ALICE M STEWART \\ From the Cancer Epidemiology Research Unit, Department of Social Medicine, University of Birmingham, \\ Edgbaston, Birmingham B15 2TH, UK
}

ABSTRACT Though most of the production work at Hanford is done by manual workers, $46 \%$ of the most dangerous jobs are performed by people who have professional or technical qualifications. For these privileged workers occupational mortality risks are positively correlated with radiation doses but for manual workers, who have relatively high death rates, there is an inverse relation with dose. The high ratio of professional to manual workers is clearly the reason for the industry having fewer observed than expected deaths and the inverse relation with dose for less privileged workers is probably a sign that there has been selective recruitment of the most highly paid manual workers - that is, skilled craftsmen into the more dangerous occupations. Evidence of this selective recruitment was obtained by equating danger levels with levels of monitoring for internal radiation. Therefore, there should be some control for these levels in any analysis of cancer effects of the measured dose of radiation.

When Marks et al compared the deaths of Hanford workers with national statistics they found that the standardised mortality ratio (SMR) was well below average for cancer (86) and even lower for other causes of death (78). ${ }^{1}$ They were also able to show that both ratios were lower for workers who remained at Hanford for more than two years $(85$ and 76$)$ than for shorter term workers ( 88 and 86$)$. They concluded that these findings were not compatible with "important adverse effects" and must have been "favourably influenced by pre-employment health screening, health insurance, and medical surveillance programmes."

These conclusions have met with general approval. No sinister significance has been attached to the relatively high SMR for cancer since it is taken for granted that pre-employment health tests are less successful in detecting cancer than other diseases. Nevertheless, we are still left with the problem of why the gap between the two SMRs was so much wider for long term than short term workers. Furthermore, there could be a non-medical reason for the low death rates that would not be expected to distinguish between different causes of death.

The alternative explanation assumes that reprocessing plants have special requirements that can be

Received 17 August 1982

Accepted 14 October 1982 met only by employing a high proportion of workers with degrees in physics, chemistry, or engineering. University graduates have a much better life expectancy than those of the same age who go straight from school to work and, age for age, they have much lower rates of cancer mortality than manual workers. Therefore, there is clearly a need to know how much of the really dangerous work at Hanford is being done by professionally or technically qualified personnel.

\section{Method}

The present study is based on a population of Hanford workers whose mortality experiences have already been used to explore relations between radiation doses and cancers of radiosensitive tissues. $^{23}$ The group included 21880 men and 6082 women and for each individual there was a set of occupational data and a set of monitoring data. The occupational data included the starting date of each new job, a brief description of the work (or job title), and census code number. ${ }^{4}$ The code numbers were poor discriminators of reprocessing jobs but they could be used to separate work which required professional or technical qualifications from lower grades of work, and to separate clerical from manual work.

There were far too many job titles (over 8000) 
and workers with different job titles for these to be used as indices of danger levels. There had, however, been universal monitoring for external or penetrating radiation (by film badges) and $61 \%$ monitoring for internal depositions of radioactive fission products (by routine urine tests). The film badges provided direct measures of radiation doses but it had evidently needed repeat urine tests and whole body counts to be quite certain that there was any internal source of radioactivity. There were very few of these confirmations ( 225 cases), but from the intensity of the monitoring it was possible to recognise four danger levels and to place each one of the job titles on this scale (table 1).

There was still no question of having only one job title for each individual and for most of the workers the period between leaving Hanford and the latest screening of death benefit claims (March 1980) was longer than the period between hire and discharge. It was therefore necessary to think in terms of manyears and to realise that there were far more years at risk of dying (follow up period) than years at risk of

Table 1 Hanford occupations: types of radiation monitoring and methods of scoring for individuals and occupations

\begin{tabular}{|c|c|c|c|}
\hline \multirow[t]{2}{*}{ Danger levels } & \multirow[t]{2}{*}{ Types of monitoring } & \multicolumn{2}{|c|}{ Annual Monitoring score } \\
\hline & & $\begin{array}{l}\text { Individual } \\
\text { workers }\end{array}$ & Occupations \\
\hline $\begin{array}{l}1 \\
2 \\
3 \\
4\end{array}$ & $\begin{array}{l}\text { Film badge only } \\
\text { Film badge and routine urine tests } \\
\text { Repeat urine tests } \\
\text { Repeat urine tests and whole body counts }\end{array}$ & $\begin{array}{l}1 \\
2 \\
3 \\
4\end{array}$ & $\begin{array}{l}1 \cdot 0-2 \cdot 4 \\
2 \cdot 5-2 \cdot 8 \\
2 \cdot 9-3 \cdot 0 \\
3 \cdot 1-4 \cdot 0\end{array}$ \\
\hline
\end{tabular}

Average monitoring score for all workers representing a given occupation in a given year.

Table 2 Hanford occupations: classifications by socioeconomic status, type of work, and danger levels

\begin{tabular}{|c|c|c|c|c|c|}
\hline \multirow[t]{2}{*}{ Socioeconomic level } & \multirow[t]{2}{*}{ Description } & \multirow[t]{2}{*}{ Census code Nos } & \multirow[t]{2}{*}{ Danger levels* } & \multicolumn{2}{|c|}{ Man-years } \\
\hline & & & & No & $\%$ \\
\hline \multirow[t]{2}{*}{1} & $\begin{array}{l}\text { Professional and } \\
\text { technical }\end{array}$ & $001-245$ & $\begin{array}{l}1 \\
2 \\
3 \\
4\end{array}$ & $\begin{array}{ll}26 & 861 \\
27 & 208 \\
25 & 584 \\
23 & 754\end{array}$ & $\begin{array}{l}2 \cdot 83 \\
2 \cdot 86 \\
2 \cdot 69 \\
2 \cdot 50\end{array}$ \\
\hline & Clerical & $301-395$ & 1 & 47598 & $5 \cdot 01$ \\
\hline \multirow[t]{3}{*}{2} & $\begin{array}{l}\text { Operatives and } \\
\text { other manual }\end{array}$ & $401-964$ & 1 & 34529 & $3 \cdot 63$ \\
\hline & & & $\begin{array}{l}2 \\
3 \\
4\end{array}$ & $\begin{array}{ll}27 & 001 \\
23 & 167 \\
33 & 828\end{array}$ & $\begin{array}{l}2 \cdot 84 \\
2 \cdot 44 \\
3 \cdot 56\end{array}$ \\
\hline & & $\begin{array}{l}\text { Hanford work years } \\
\text { Post Hanford } \\
\text { Follow up period }\end{array}$ & & $\begin{array}{l}269530 \\
680990 \\
950520\end{array}$ & $\begin{array}{l}28 \cdot 36 \\
71 \cdot 64 \\
100 \cdot 00\end{array}$ \\
\hline
\end{tabular}

* See table 1 .

Table 3 Hanford occupations: relations between socioeconomic levels, radiation doses, and differential mortality. (Figures in parentheses are ranking positions within each socioeconomic level)

\begin{tabular}{|c|c|c|c|c|c|}
\hline $\begin{array}{l}\text { Socioeconomic } \\
\text { levels }\end{array}$ & Occupations & $\begin{array}{l}\text { Danger } \\
\text { levels* }\end{array}$ & $\begin{array}{l}\text { Monitoring scores } \\
\text { (means) }\end{array}$ & $\begin{array}{l}\text { External radiation } \\
\text { mean annual dose in } \\
\text { millirems }\end{array}$ & $\begin{array}{l}\text { Differential mortality } \\
\text { scores }{ }^{\dagger}\end{array}$ \\
\hline 1 & Professional and technical & $\begin{array}{l}1 \\
2 \\
3 \\
4\end{array}$ & $\begin{array}{l}1.92(1) \\
2.74(2) \\
3.08(3) \\
3.69(4)\end{array}$ & $\begin{array}{r}87(1) \\
168(2) \\
260(3) \\
639(4)\end{array}$ & $\begin{array}{l}-228(1) \\
-210(3) \\
-222(2) \\
-\quad 29(4)\end{array}$ \\
\hline \multirow[t]{2}{*}{2} & Clerical & 1 & $2 \cdot 03(1)$ & $37(1)$ & $+92(5)$ \\
\hline & Operatives and other manual & $\begin{array}{l}1 \\
2 \\
3 \\
4\end{array}$ & $\begin{array}{l}2 \cdot 28(2) \\
2 \cdot 76(3) \\
3 \cdot 20(4) \\
3 \cdot 60(5)\end{array}$ & $\begin{array}{l}61(2) \\
126(3) \\
166(4) \\
831(5)\end{array}$ & $\begin{array}{l}+\quad 65(3) \\
+\quad 82(4) \\
-\quad 43(1) \\
-\quad 35(2)\end{array}$ \\
\hline
\end{tabular}

* See table 1 .

†These indices of general mortality measure the change in logit probability $\left(\times 10^{4}\right)$ of the death rates being higher $(+)$ or lower $(-)$ than the average for all workers with control for age, sex, and calendar year. 
any occupational hazard (Hanford work years).

\section{Findings}

There were 950520 man-years for the follow up period as a whole and 269530 for Hanford work years. Jobs requiring professional or technical qualifications accounted for 103407 or $38.7 \%$ of the Hanford work years and lower grades of work for 166123 or $61.6 \%$ of those years. For clerical work the corresponding figures were 47598 or $17.6 \%$ and for manual work 118525 or $43.0 \%$ (table 2). Division of non-clerical job titles between four danger levels left the lower half of this monitoring scale with 115599 man-years and the upper half with 106333 years. For work requiring professional or technical qualifications the corresponding figures were 54069 or $46.8 \%$ for the lower half of the scale and 49333 or $46.4 \%$ for the upper half. Therefore, nearly half the really dangerous work at Hanford was being done by personnel who probably account for less than $20 \%$ of the working age population of the United States - that is, those with professional or technical qualifications.

Table 3 shows that, for Hanford workers, monitoring levels and doses of external radiation go hand in hand. This is equally true of work requiring professional or technical qualifications and lower grades of work, but relations between danger levels and mortality are very different for the two grades of work. Thus for work requiring specialist qualifications the safest jobs were associated with the lowest risk of dying and the most dangerous jobs with the highest risk, and for other grades of work (including clerical) the opposite was true. Furthermore, levels of mortality were so much higher for the lower than the higher grades of work that it was only for specialists and non-specialists doing the most dangerous jobs that there was any comparability of mortality risks.

\section{Discussion}

During the interval that has elapsed since Marks and his associates discovered that Hanford workers have low SMRs for cancer, and even lower ratios for other causes of death, ${ }^{1}$ there has been no attempt to discover why this is so or how the selection bias was related to subsequent radiation exposures. This was probably the result of interested parties being content to ascribe the bias to pre-employment health tests but there were also difficulties because there were over 8000 separate job titles, many changes of occupation by individual workers, and no certainty about how the different occupations were related to socioeconomic factors such as income and education.

The present investigation has shown that these difficulties can be overcome by equating danger levels with degrees of monitoring for internal radiation, and drawing a distinction between work that requires professional or technical qualifications (and can be recognised as a distinctive type of work in the census) and lower grades of work, and separating clerical from manual workers. These procedures made it possible for over 8000 job titles to be compressed into nine occupational groups preparatory to obtaining a measure of general mortality risks for each group.

Separation of the two grades of work has proved to be of the utmost importance for two reasons: evidently the low SMRs are a direct consequence of Hanford employing a high proportion of well educated workers who can earn high salaries, and for lower grades of workers there is an inverse relation between job related mortality risks and radiation doses. Therefore, there must be selective recruitment into the dangerous occupations, which probably makes this type of work the perogative of personnel with specialist qualifications (principals) and skilled craftsmen (assistants).

It follows from these observations that it was sensible to include levels of monitoring for internal radiation as controlling factors in MSK analyses of Hanford data. ${ }^{23}$ Critics of these analyses have objected on various grounds including the fact that all criteria for placing the workers in different cohorts should be settled in advance of any radiation exposures. ${ }^{3}$ Therefore, it was clearly desirable to obtain monitoring levels for jobs as well as individuals. This has been done and the results show that monitoring is an excellent predictor of radiation doses. The next step will be to obtain exact estimates of job related mortality risks in a form that can be used as a controlling factor in the future studies of radiation effects.

The cost of this analysis was borne by a grant from the United States National Institute of Occupational Safety and Health (grant No 5 RO1 08 00929-02).

\section{References}

' Marks S, Gilbert ES, Breitenstein BD. Cancer mortality in Hanford workers. In: Late biological effects of ionizing radiation. Vol I. Vienna: International Atomic Energy Authority, $1978 ; 369-84$.

${ }^{2}$ Mancuso TF, Stewart AM, Kneale GW. Hanford IIA: reanalysis of data relating to the Hanford study of the cancer risks of radiation workers. In: Late biological effects of ionizing radiation. Vol I. Vienna: International Atomic Energy Authority, 1978;387-410.

${ }^{3}$ Kneale GW, Mancuso TF, Stewart AM. Hanford radiation study III: a cohort study of the cancer risks from radiation to workers at Hanford (1944-77 deaths) by the method of regression models in life-tables. $\mathrm{Br} J$ Ind Med 1981;38:156-66.

${ }^{4}$ US Department of Commerce. Classified index by industries and occupations 1971. Washington: US DC, 1971. 